Die

\title{
Hieracien Mittel-Europas.
}

Monographische Bearbeitung

der

\section{Piloselloiden}

mit besonderer Berücksichtigngg

der

mitteleuropäischen Sippen

von

C. v. Nägeli und A. Peter.

Munchen.

Druck und Verlag von R. Oldenbourg.

1885. 
